DOI: https://doi.org/10.31933/jimt.v2i6 Received: 8 April 2021, Revised: 25 Mei 2021, Publish: 21 Juli 2021

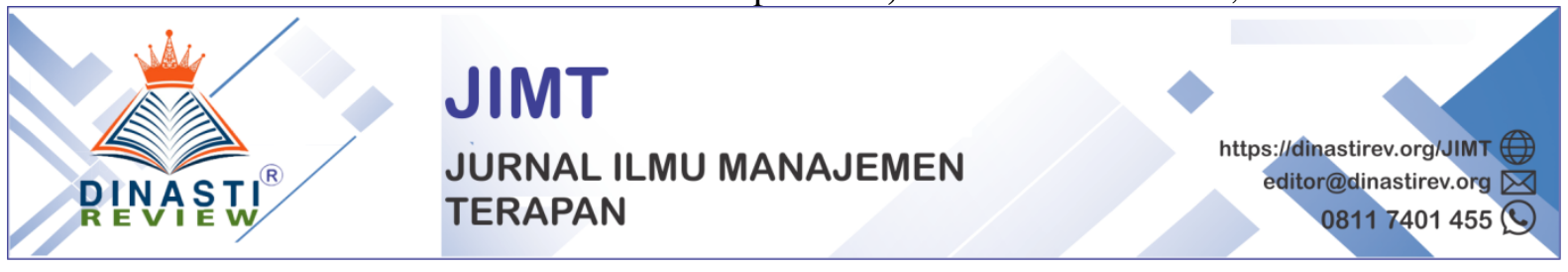

\title{
ALTERNATIF PENYELESAIAN SENGKETA DAN ARBITRASE (LITERATURE REVIEW ETIKA)
}

\author{
Firda Ainun Fadillah', Saskia Amalia Putri \\ ${ }^{1)}$ Mahasiswa Program Magister Akuntansi, Universitas Mercu Buana Jakarta, firdaainunfadillah@gmail.com \\ ${ }^{2)}$ Mahasiswa Program Magister Akuntansi, Universitas Mercu Buana Jakarta, fsaskia.amaliaaa22@gmail.com
}

\section{Corresponding Author: Saskia Amalia Putri ${ }^{2}$}

\begin{abstract}
Abstrak: Pertumbuhan ekonomi yang pesat dan kompleks melahirkan berbagai macam bentuk kerjasama bisnis. Mengingat kegiatan bisnis semakin meningkat dari hari kehari, maka tidak mungkin dihindari terjadinya sengketa (dispute/diference) diantara para pihak yang terlibat. Sengketa muncul dikarenakan berbagai alasan dan masalah yang melatar belakanginya, terutama karena adanya conflict of interest di antara para pihak. Sengketa yang timbul di antara pihak-pihak yang terlibat dalam berbagai macam kegiatan bisnis atau perdagangan dinamakan sengketa bisnis. Di Negara kita fenomena penggunaan mekanisme Alternative Dispute Resolution semakin menguat. Alternative Dispute Resolution dipandang sebagai integral dari bisnis itu sendiri dan dianggap cocok untuk dunia bisnis karena penyelesaiannya cepat dan biaya murah.Penyelesaian sengketa sebagai mediasi telah dikenal sejak yang pertama di Indonesia karena sistem adat dalam menyelesaikan kasus selalu menjunjung tinggi musyawarah dan mufakat melalui forum tradisional masing-masing daerah di Indonesia. Seperti tumbuh oleh waktu, ini ditegakkan di pengadilan (Pengadilan Terhubung Mediasi) sebagai bentuk hukum keadilan. Namun, proses mediasi di pengadilan harus ditegakkan melalui penyelesaian sengketa perdata. Jika mediasi sebagaimana diatur dalam Peraturan Mahkamah Agung Nomor 1 Tahun 2008, jika mediasi tidak dilaksanakan, penghakiman akan dihilangkan untuk tujuan hukum.
\end{abstract}

Kata Kunci: Alternatif penyelesaian sengketa, e-commerce, arbitrase, arbitrase online.

\section{INTRODUCTION}

\section{Latar Belakang Masalah.}

Cara penyelesaian sengketa pada dasarnya sudah ada sejak zaman dahulu mengikuti perkembangan peradaban manusia. Manusia diciptakan tuhan dengan berbagai karakter, ras suku yang berbeda-beda, dengan perbedaan tersebut manusia tidak terlepas dari konflik, baik dengan manusia lainnya, alam lingkungannya, bahkan dengan dirinya sendiri. 
Namun dengan akal pikiran manusia akan selalu berusaha untuk mencari bagaimana cara penyelesaian konflik dalam rangka mencapai posisi keseimbangan dan kerukunan hidup di antara sesamanya. Pada dasarnya penyelesaian sengketa dapat dilakukan dengan dua cara, yang biasa digunakan adalah penyelesaian sengketa melalui pengadilan, kemudian dengan perkembangan peradaban manusia berkembang pula penyelesaian sengketa di luar pengadilan.

Proses penyelesaian sengketa melalui pengadilan menghasilkan suatu keputusan yang bersifat adversarial yang belum mampu merangkul kepentingan bersama, karena menghasilkan suatu putusan win lose solution, dengan adanya pihak yang menang dan kalah tersebut, di satu pihak akan merasa puas tapi di pihak lain merasa tidak puas, sehingga dapat menimbulkan suatu persoalan baru di antara para pihak yang bersengketa.

Belum lagi proses penyelesaian sengketa yang lambat, waktu yang lama, dan biaya yang relatif lebih mahal. Sedangkan proses penyelesaian sengketa di luar pengadilan, menghasilkan kesepakatan yang "win-win solution" karena penyelesaian sengketa di luar pengadilan melalui kesepakatan dan musyawarah di antara para pihak sehingga dapat menghasilkan suatu keputusan bersama yang dapat diterima baik oleh kedua belah pihak, dan keputusan yang dihasilkan dapat dijamin kerahasiaan sengketa para pihak karena tidak ada kewajiban untuk proses persidangan yang terbuka untuk umum dan dipublikasikan. Penyelesaian sengketa di luar pengadilan ini umumnya dinamakan Alternative Dispute Resolution (ADR).

Alternative Dispute Resolution (ADR) merupakan istilah yang pertama kali muncul di Negara Amerika Serikat. Konsep ADR merupakan jawaban atas ketidakpuasan (dissatisfaction) yang muncul di tengah kehidupan masyarakat di Amerika terhadap system pengadilannya. Ketidakpuasan tersebut muncul karena penyelesaian sengketa melalui pengadilan memakan waktu yang cukup lama karena adanya penumpukan perkara di pengadilan, sehingga membutuhkan biaya yang cukup besar, serta keraguan masyarakat terhadap kemampuan hakim dalam menyelesaikan persoalan-persoalan yang bersifat rumit yang memerlukan keahlian tertentu untuk menyelesaikannya.

Kerumitan tersebut dapat disebabkan oleh substansi kasus yang sarat dengan persoalan ilmiah (scientifically complicated) atau dapat juga karena banyaknya serta luasnya stake holders yang harus terlibat. Oleh sebab itulah para praktisi hokum dan para akademisi mengembangkan Alternative Dispute Resolution (ADR) sebagai penyelesaian sengketa yang mampu menjembatani kebutuhan masyarakat yang mencari keadilan dalam menyelesaikan sengketa di antara mereka.

Di Indonesia, proses penyelesaian sengketa melalui ADR bukanlah sesuatu yang baru dalam nilai-nilai budaya bangsa, karena jiwa dan sifat masyarakat Indonesia dikenal dengan sifat kekeluargaan dan kooperatif dalam menyelesaikan masalah. Di berbagai suku bangsa di Indonesia biasanya menggunakan cara penyelesaian musyawarah dan mufakat untuk mengambil keputusan. Misalnya saja di batak dalam forum runggun adatnya menyelesaikan sengketa secara musyawarah dan kekeluargaan, di minang kabau, dikenal adanya lembaga hakim perdamaian yang secara umum berperan sebagai mediator dan konsiliator dalam menyelesaikan suatu masalah yang dihadapi oleh masyarakat setempat. 3 Oleh sebab itu masuknya konsep ADR di Indonesia tentu saja dapat dengan mudah diterima oleh masyarakat Indonesia. 
Artikel ini menganalisis Penyelesaian Sengketa $\left(\mathrm{X}_{1}\right)$ Persaingan Usaha $\left(\mathrm{X}_{2}\right)$, terhadap arbitrase ( $\left.\mathrm{Y}_{1}\right)$, suatu studi literatur Manajemen Strategis.

\section{Rumusan Masalah.}

Berdasarkan latar belakang akan di rumuskan masalah yang akan di bahas pada artikel literature review agar lebih focus pada kajian pustaka dan hasil serta pembahasan nanti, yaitu:

1. Menjelaskan mengenai pengertian sengketa dan pengelompokannya.

2. Menyebutkan beberapa cara alternatif penyelesaian sengketa

3. Menjelaskan pengaturan arbitrase, UU No. 30 Tahun 1999.

4. Menyebutkan kelebihan dan kelemahan arbitrase.

5. Menjelaskan etika dalam berabitrase.

6. Bagaimana penyelesaian sengketa sebelum adanya Alternative Dispute Resolution (ADR)

\section{KAJIAN TEORI \\ Penjelasan Sengketa}

Sengketa dapat terjadi pada siapa saja dan dimana saja. Sengketa dapat terjadi antara individu dengan individu, antara individu dengan kelompok, antara kelompok dengan kelompok, antara perusahaan dengan perusahaan, antara perusahaan dengan negara, antara negara satu dengan yang lainnya, dan sebagainya. Dengan kata lain, sengketa dapat bersifat publik maupun bersifat keperdataan dan dapat terjadi baik dalam lingkup lokal, nasional maupun internasional.

Sengketa adalah suatu situasi dimana ada pihak yang merasa dirugikan oleh pihak lain, yang kemudian pihak tersebut menyampaikan ketidakpuasan ini kepada pihak kedua. Jika situasi menunjukkan perbedaan pendapat, maka terjadi lah apa yang dinamakan dengan sengketa. Dalam konteks hukum khususnya hukum kontrak, yang dimaksud dengan sengketa adalah perselisihan yang terjadi antara para pihak karena adanya pelanggaran terhadap kesepakatan yang telah dituangkan dalam suatu kontrak, baik sebagian maupun keseluruhan. Dengan kata lain telah terjadi wanprestasi oleh pihak-pihak atau salah satu pihak (Nurnaningsih Amriani, 2012: 12).

Menurut Nurnaningsih Amriani (2012: 13), yang dimaksud dengan sengketa adalah perselisihan yang terjadi antara pihak-pihak dalam perjanjian karena adanya wanprestasi yang dilakukan oleh salah satu pihak dalam perjanjian.

Hal yang sama juga disampaikan oleh Takdir Rahmadi (2011: 1) yang mengartikan bahwa konflik atau sengketa merupakan situasi dan kondisi di mana orang-orang saling mengalami perselisihan yang bersifat faktual maupun perselisihanperselisihan yang ada pada persepsi mereka saja Dengan demikian, yang dimaksud dengan sengketa ialah suatu perselisihan yang terjadi antara dua pihak atau lebih yang saling mempertahankan persepsinya 
masing-masing, di mana perselisihan tersebut dapat terjadi karena adanya suatu tindakan wanprestasi dari pihak-pihak atau salah satu pihak dalam perjanjian.

\section{Persaingan Usaha}

Menurut Marbun (2003) adalah usaha dari dua pihak/lebih perusahaan yang masingmasing bergiat memperoleh pesanan dengan menawarkan harga/syarat yang paling menguntungkan. Persaingan adalah ketika organisasi atau perorangan berlomba untuk mencapai tujuan yang diinginkan seperti konsumen, pangsa pasar,peringkat survei, atau sumber daya yang dibutuhkan.Persaingan usaha dilakukan untuk merebut hati konsumen. Para pelaku usaha berusaha menawarkan produk dan jasa yang menarik, baik dari segi harga, kualitas dan pelayanan.

Kombinasi ketiga faktor tersebut untuk memenangkan persaingan merebut hati para konsumen dapat diperoleh melalui inovasi, penerapan teknologi yang tepat, serta kemampuan manajerial untuk mengarahkan sumber daya perusahaan dalam memenangkan persaingan. Pelaku usaha jarang sekali hanya berdiri sendiri dalam menjual ke suatu pasar pelanggan tertentu.

Perusahaan bersaing dengan sejumlah pesaing. Pesaing-pesaing ini harus diidentifikasi, dimonitori dan disiasati untuk memperoleh dan mempertahankan loyalitas pelanggan. Jika terjadi proses persaingan antara para pelaku usaha, maka mereka akan berupaya mencapai tujuannya dengan saling mengungguli dalam mendapatkan konsumen dan pangsa pasar.

Pengertian kebijakan persaingan dalam kamus lengkap ekonomi, karya Christopher pass dan Bryan Lowes adalah kebijakan yang berkaitan dengan meningkatkan efisiensi pemakaian sumber daya dan perlindungan kepentingan konsumen. Tujuan kebijakan persaingan adalah untuk menjamin terlaksananya pasar yang optimal, khususnya biaya produksi yang terendah, harga dan tingkat keuntungan yang wajar, kemajuan teknologi, dan pengembangan produk.

Sedangkan menurut Hermansyah, pokok-pokok hukum persaingan usaha di Indonesia, menambahkan bahwa kebijakan persaingan usaha adalah kebijakan yang berkaitan dengan masalah masalah Di bidang persaingan usaha yang harus dipedomani oleh pelaku usaha dalam menjalankan usahanya dan melindungi kepentingan konsumen.

Persaingan Usaha sudah banyak di teliti oleh peneliti sebelumnya diantaranya adalah: (Effendi B., 2020 ), ( Darmaryanti H., Utomo S., Annurdi A., 2020 ).

\section{Penyelesaian Sengketa Arbitrase}

Dalam penyelesaian sengketa melalui non-litigasi, kita telah mengenal adanya penyelesaian sengketa alternatif atau Alternative Dispute Resolution (ADR), yang dalam perspektif Undang-Undang Nomor 30 tahun 1999 tentang Arbitrase dan Alternatif Penyelesaian Sengketa, Alternative Dispute Resolution adalah suatu pranata penyelesaian sengketa di luar pengadilan berdasarkan kesepakatan para pihak dengan mengesampingkan penyelesaian sengketa secara litigasi di pengadilan.

Akhir-akhir ini pembahasan mengenai alternatif dalam penyelesaian sengketa semakin ramai dibicarakan, bahkan perlu dikembangkan untuk mengatasi kemacetan dan penumpukan perkara di pengadilan maupun di Mahkamah Agung (Buku Tanya Jawab PERMA No.1 Tahun 
2008 tentang Prosedur Mediasi di Pengadilan, 2008: 1). Salah satunya penyelesaian sengketa yaitu dengan Arbitrase.

Arbitrase Pasal 1 ayat (1) Undang-Undang Nomor 30 tahun 1999 tentang Arbitrase dan Alternatif Penyelesaian Sengketa menjelaskan bahwa arbitrase (wasit) adalah cara penyelesaian suatu sengketa perdata di luar pengadilan umum yang didasarkan pada perjanjian arbitrase yang dibuat secara tertulis oleh para pihak yang bersengketa. Arbitrase digunakan untuk mengantisipasi perselisihan yang mungkin terjadi maupun yang sedang mengalami perselisihan yang tidak dapat diselesaikan secara negosiasi/konsultasi maupun melalui pihak ketiga serta untuk menghindari penyelesaian sengketa melalui Badan Peradilan yang selama ini dirasakan memerlukan waktu yang lama.

\section{METODE PENULISAN}

Metode penulisan artikel ilmiah ini adalah dengan metode kualitatif dan studi literature atau Library Research. Mengkaji Buku-buku literature sesuai dengan teori yang di bahas khusunya di lingkup Manajemen Strategis . Disamping itu menganalisis artikel-artikel ilmiah yang bereputasi dan juga artikel ilmiah dari jurnal yang belum bereputasi. Semua artikel ilmiah yang di citasi bersumber dari Mendeley.

Dalam penelitian kualitatif, kajian pustaka harus digunakan secara konsisten dengan asumsi-asumsi metodologis. Artinya harus digunakan secara induktif sehingga tidak mengarahkan pertanyaan-pertanyaan yang diajukan oleh peneliti. Salah satu alasan utama untuk melakukan penelitian kualitatif yaitu bahwa penelitian tersebut bersifat eksploratif, (Ali \& Limakrisna, 2013).

Selanjutnya dibahas secara mendalam pada bagian yang berjudul" Pustaka Terkait" (Related Literature) atau Kajian pustaka("Review of Literature"), sebagai dasar perumusan hipotesis dan selanjutnya akan menjadi dasar untuk melakukan perbandingan dengan hasil atau temuan-temuan yang terungkap dalam penelitian, (Ali \& Limakrisna, 2013).

\section{PEMBAHASAN}

Artikel ini menganalis dan membahas tentang Penyelesaian Sengketa yaitu:

Persaingan Usaha dalam penyelesaian sengketa,dengan menggunakan Arbitrase. Riset dan artikel terdahulu dan relevan dengan artikel ini di antarnya adalah:

\section{Pengertian sengketa dan pengelompokan nya}

Pertama-tama yang perlu Anda ketahui adalah bahwa dalam setiap kegiatan atau hubungan baik antarindividu, antara individu dan institusi (atau badan hukum), maupun antarinstitusi dapat saja terjadi perbedaan, misalnya perbedaan pendapat, pandangan, penafsiran, sikap, perilaku, dan lain-lain.

Perbedaan-perbedaan tersebut wajar, tetapi apabila tidak terselesaikan dengan baik maka dapat menimbulkan perselisihan. Perselisihan yang perlu diselesaikan inilah yang disebut dengan sengketa.

Selanjutnya, Anda akan menemukan berbagai macam atau bentuk sengketa yang sangat beraneka ragam, tergantung dengan hal-hal yang melatarbelakanginya dan para pihak yang terlibat di dalamnya. Untuk menentukan macam dan bentuk sengketa tersebut seringkali diperlukan kemampuan analisis yang mendalam dan dilakukan 
secara teliti. Mengenai siapa saja yang dapat bersengketa, hal ini pun sangat dipengaruhi oleh obyek yang disengketakan.

Oleh karena itu, berdasarkan pihak-pihak yang bersengketa maka sengketa dapat dikelompokan ke dalam bidang-bidang tertentu. yang batas-batasnya dapat saja bersifat tumpang-tindih, yaitu:

1. Sengketa antarindividu, misalnya perselisihan dalam keluarga akibat perceraian seperti masalah anak, pembagian harta benda, warisan, dan lainlain.

2. Sengketa antara individu dan badan hukum, misalya masalah ketenagakerjaan di mana perselisihan timbul antara pegawai dan perusahaan mengenai upah, jam kerja, pemberian pesangon, dan lain-lain.

3. Sengketa antarbadan hukum, misalnya perselisihan antar korporasi di mana perusahaan yang satu menggugat perusahaan lainnya.

Perlu Anda ketahui bahwa pada dasarnya tidak seorang pun menghendaki terjadinya sengketa dengan orang lain. Tetapi dalam setiap hubungan, khususnya dalam kegiatan bisnis, masing-masing pihak harus selalu siap mengantisipasi kemungkinan timbulnya sengketa yang dapat terjadi setiap saat di kemudian hari. Misalnya dalam suatu perjanjian, sengketa yang perlu diantisipasi dapat timbul karena perbedaan penafsiran baik mengenai bagaimana "cara" melaksanakan klausul-klausul perjanjian maupun tentang apa "isi" dari ketentuan-ketentuan di dalam perjanjian, ataupun disebabkan hal-hal lainnya.

Untuk menyelesaikan kemungkinan terjadinya sengketa, Anda memiliki beberapa pilihan cara penyelesaian. Pada umumnya beberapa cara yang dapat dipilih dibedakan melalui pengadilan atau di luar pengadilan seperti negosiasi, konsiliasi, konsultasi, penilaian ahli, mediasi, arbitrase dan lainlain, yang sering disebut sebagai alternatif penyelesaian sengketa (APS). Untuk cara APS (kecuali arbitrase) biasanya dilakukan dengan mendiskusikan perbedaan-perbedaan yang timbul di antara para pihak yang bersengketa melalui "musyawarah untuk mufakat" dengan tujuan mencapai win-win solution. Jadi, apakah sengketa tersebut dapat diselesaikan atau tidak sangat tergantung pada keinginan dan itikad baik para pihak yang bersengketa.

Artinya, bagaimana mereka mampu menghilangkan perbedaan pendapat di antara mereka. Apabila penyelesaian secara damai telah disepakati oleh para pihak, mereka terikat pada hasil penyelesaian tersebut. (Lihat Pasal 6 UU No. 30 Tahun 1999 tentang Arbitrase dan Alternatif Penyelesaian Sengketa, selanjutnya disingkat UU No. 30 Tahun 1999) Namun demikian, terlepas dari perbedaan pengertian APS, pada umumnya cara-cara yang paling sering digunakan oleh para pihak yang bersengketa adalah negosiasi, mediasi, arbitrase, dan pengadilan, yang ketiga cara pertama (kecuali pengadilan) akan menjadi topik bahasan utama dari buku ini.

\section{Cara alternatif penyelesaian sengketa}

Pada dasarnya adalah cara penyelesaian yang dilakukan di luar pengadilan sebagai alternatif dari pengadilan. Jadi, cara penyelesaian alternatif ini, atau dalam pengertian tersebut, di dalamnya termasuk arbitrase. Namun demikian, pengertian APS yang memasukkan arbitrase 
merupakan pengertian dalam arti luas, sedangkan dalam arti sempit arbitrase tidak masuk pengertian APS.Hal ini mengingat arbitrase pada dasarnya juga merupakan "pengadilan" (atau sering pula disebut pengadilan swasta untuk membedakannya dengan pengadilan negara) yang putusannya didasarkan pada menang-kalah (win-lose).

Untuk memudahkan pembahasan, Anda harus membedakan antara APS yang putusannya adalah win-win dan arbitrase yang win-lose sehingga keduanya perlu dipisahkan. Pembedaan ini juga sesuai dengan Undang-Undang Nomor 30 Tahun 1999 tentang Arbitrase dan Alternatif Penyelesaian Sengketa. Dari nama undang-undang tersebut, yaitu "Arbitrase dan Alternatif Penyelesaian Sengketa", pembentuk undang-undang jelas menghendaki dipisahkannya arbitrase dan APS. Meskipun demikian, dengan pembedaan tersebut, beberapa cara penyelesaian sengketa berdasar APS yang diatur dalam undang-undang tersebut ternyata telah menimbulkan beberapa masalah.

Dalam Pasal 6 ayat (2) UU No. 30 Tahun 1999 disebutkan bahwa "Penyelesaian sengketa atau beda pendapat melalui alternatif penyelesaian sengketa diselesaikan dalam pertemuan langsung oleh para pihak dalam waktu paling lama 14 (empat belas) hari dan hasilnya dituangkan dalam suatu kesepakatan tertulis." Tidak ada penjelasan lebih jauh tentang hal yang dimaksud dengan "pertemuan langsung" itu. Jadi, secara subjektif dapat ditafsirkan bahwa yang dimaksud dengan penyelesaian sengketa dengan cara bertemu secara langsung tersebut disebut negosiasi.

Demikian pula, jika ketentuan Pasal tersebut Anda perhatikan maka akan muncul pertanyaan-pertanyaan susulan seperti:

1. Apakah yang dimaksud dengan pertemuan langsung adalah keharusan untuk bertemu (tatap) muka, atau dapat dilakukan melalui media elektronik (teleconference) atau melalui surat menyurat secara langsung, misalnya menggunakan e-mail, atau chatting melalui internet, atau bagaimana jika para pihak tidak dapat bertemu langsung (bertatap muka), apakah negosiasi tersebut sah menurut undang-undang tersebut?

2. Bagaimana menghitung tenggang waktu 14 hari; apakah sejak pemberitahuan setuju untuk melakukan negosiasi (meskipun para pihak belum bertemu tatap muka), atau sejak dilakukannya pertemuan pertama (yang biasanya hanya untuk berbasa-basi, tetapi belum membahas pokok permasalahan), atau sejak dilakukannya pertemuan yang telah masuk pada pembahasan mengenai sengketa? Kelemahan tersebut sebenarnya hanya sebagian kecil dari begitu banyak persoalan yang mungkin timbul jika sengketa diselesaikan melalui APS dengan mengacu pada UU No. 30 Tahun 1999.

\section{MACAM-MACAM ALTERNATIF PENYELESAIAN SENGKETA}

a. Negosiasi

Negosiasi adalah cara untuk mencari penyelesaian masalah melalui diskusi (musyawarah) secara langsung antara pihak-pihak yang bersengketa yang hasilnya diterima oleh para pihak tersebut. Dari pengertian tersebut, Anda dapat merasakan bahwa negosiasi tampak lebih sebagai suatu seni untuk mencapai kesepakatan daripada ilmu pengetahuan yang dapat dipelajari. Dalam praktik, negosiasi dilakukan karena 2 (dua) alasan, yaitu: 
untuk mencari sesuatu yang baru yang tidak dapat dilakukannya sendiri, misalnya dalam transaksi jual beli, pihak penjual, dan pembeli saling memerlukan untuk menentukan harga (di sini tidak terjadi sengketa), untuk memecahkan perselisihan atau sengketa yang timbul di antara para pihak.

b. Mediasi

Pengertian mediasi antara lain adalah upaya penyelesaian sengketa dengan melibatkan pihak ketiga yang netral, yang tidak memiliki kewenangan mengambil keputusan, yang membantu pihak-pihak yang bersengketa mencapai penyelesaian (solusi) yang diterima oleh kedua belah pihak.

Jika kita perhatikan pengertian mediasi tersebut, sebenarnya mediasi sulit didefinisikan karena pengertian tersebut sering digunakan oleh para pemakainya dengan tujuan yang berbeda-beda, sesuai dengan kepentingan mereka masing-masing. Misalnya, di beberapa negara karena pemerintahnya menyediakan dana untuk lembaga mediasi bagi penyelesaian sengketa komersial, banyak lembaga lain menyebut dirinya sebagai lembaga mediasi. Jadi, di sini mediasi sengaja dirancukan dengan istilah lainnya, misalnya konsiliasi, rekonsiliasi, konsultasi, atau bahkan arbitrase.

c. Konsiliasi

Hal yang menarik mengenai konsiliasi adalah konsiliasi pada dasarnya hampir sama dengan mediasi, mengingat terdapat keterlibatan pihak ke-3 yang netral (yang tidak memihak) yang diharapkan dapat membantu para pihak dalam upaya penyelesaian sengketa mereka, yaitu konsiliator.

Namun demikian, Anda perlu perhatikan bahwa konsiliator pada umumnya memiliki kewenangan yang lebih besar daripada mediator, mengingat ia dapat mendorong atau "memaksa" para pihak untuk lebih kooperatif dalam penyelesaian sengketa mereka. Konsiliator pada umum dapat menawarkan alternatif-alternatif penyelesaian yang digunakan sebagai bahan pertimbangan oleh para pihak untuk memutuskan. Jadi, hasil konsiliasi, meskipun merupakan kesepakatan para pihak, adalah sering datang dari si konsiliator dengan cara "mengintervensi". Dalam kaitan itu, konsiliasi dalam banyak hal mirip dengan mediasi otoritatif di mana mediator juga lebih banyak mengarahkan para pihak.

\section{Pengaturan arbitrase UU No. 30 Tahun 1999}

Pada dasarnya, arbitrase merupakan cara penyelesaian sengketa di luar peradilan, berdasarkan pada perjanjian arbitrase yang dibuat oleh para pihak, dan dilakukan oleh arbiter yang dipilih dan diberi kewenangan mengambil keputusan. Arbitrase merupakan pilihan yang paling menarik, khususnya bagi kalangan pengusaha. Bahkan, arbitrase dinilai sebagai suatu "pengadilan pengusaha" yang independen guna menyelesaikan sengketa yang sesuai dengan keinginan dan kebutuhan mereka.

Dalam Pasal 5 ayat (1) Undang-Undang No. 30 Tahun 1999 tentang Arbitrase dan Alternatif Penyelesaian Sengketa (untuk selanjutnya disingkat UU No. 30 Tahun 1999) disebutkan bahwa: "Sengketa yang dapat diselesaikan melalui arbitrase hanya sengketa di bidang perdagangan dan hak yang menurut hukum dan peraturan perundang-undangan dikuasai sepenuhnya oleh pihak yang bersengketa." Dengan demikian, sengketa seperti kasus-kasus 
keluarga atau perceraian, yang hak atas harta kekayaan tidak sepenuhnya dikuasai oleh masingmasing pihak, tidak dapat diselesaikan melalui arbitrase.

\section{Kelebihan dan kelemahan arbitrase}

Kata arbitrase berasal dari bahasa Latin arbitrare yang artinya kekuasaan untuk menyelesaikan sesuatu menurut "kebijaksanaan" (Subekti, 1981: 1 - 3). Jika Anda hanya memerhatikan secara sepintas maka dikaitkannya istilah arbitrase dengan kebijaksanaan seolah-olah memberi petunjuk bahwa majelis arbitrase tidak perlu memerhatikan hukum dalam menyelesaikan sengketa para pihak tetapi cukup mendasarkan pada kebijaksanaan.

Pandangan tersebut keliru karena arbiter juga menerapkan hukum seperti apa yang dilakukan oleh hakim di pengadilan. Dalam memeriksa dan memutus suatu sengketa, arbiter atau majelis arbitrase selalu mendasarkan diri pada hukum, yaitu hukum yang telah dipilih oleh para pihak yang bersengketa (choice of law).

Meskipun demikian, tidak tertutup kemungkinan bahwa para arbiter, apabila dikehendaki oleh para pihak, dapat memutus atas dasar keadilan dan kepatutan (ex aequo et bono). Dalam Penjelasan UU No. 30 Tahun 1999 disebutkan bahwa jika arbiter diberi kebebasan untuk memberikan putusan berdasarkan keadilan dan kepatutan, maka peraturan perundang-undangan dapat dikesampingkan. Akan tetapi dalam hal tertentu, hukum memaksa (dwingende regels) harus diterapkan dan tidak dapat disimpangi oleh arbiter.

Jika arbiter tidak diberi kewenangan untuk menjatuhkan putusan berdasarkan keadilan dan kepatutan, maka arbiter hanya dapat memberi putusan berdasarkan kaidah hukum materiil sebagaimana dilakukan oleh hakim.

\section{Berikut adalah kelebihan dan kekukrangan arbitse}

\section{Kelebihan arbitrase adalah sebagai berikut:}

1. Prosedur tidak berbelit dan keputusan dicapai dalam waktu relative singkat

2. Biaya lebih murah.

3. Dapat dihindari ekspose dari keputusan di didepan umum

4. Hukum terhadap prosedur dan pembuktian lebih kekeluargaan

5. Para pihak dapat memilih hukum mana yang akan diberlakukan oleh arbitrase

6. Para pihak dapat memilih sendiri para arbiter

7. Dapat dipilih para arbiter dari kalangan ahli dalam bidangnya

8. Keputusan dapat lebih terkait dengan situasi dan kondisi

9. Keputusan arbitrase umumnya final binding (tanpa harus naik banding atau kasasi)

10. Keputusan arbitrase umumnya dapat diberlakukan dan dieksekusi oleh pengadilan

11. Proses/prosedur arbitrase lebih mudah dimengerti oleh masyarakat luas.

\section{Adapun kekurangan arbitrase adalah sebagai berikut:}

1. Kemungkinan hanya baik dan tersedia dengan baik terhadap perusahaan-perusahaan bonafide.

2. Kurangnya unsur finality

3. Kurangnya power untuk menghadirkan barang bukti, saksi, dan lain-lain

4. Kurangnya power untuk law enforcement dan eksekusi keputusan

5. Tidak dapat menghasilkan solusi yang bersifat prefentif 
6. Kemungkinan timbulnya keputusan yang saling bertentangan satu sama lain karena tidak ada system "precedent" terhadap keputusan sebelumnya, dan juga karena unsure fleksibilitas dari arbiter. Karena itu keputusan arbitrase tidak predektif

7. Kualitas keputusannya sangat bergantung pada kualitas para arbiter itu sendiri, tanpa ada norma yang cukup untuk menjaga standar mutu keputusan arbitrase.

\section{Etika dalam berabitrase.}

Secara internasional telah dikeluarkan seperangkat petunjuk etika bagi arbiter internasional (Ethics for International Arbitrators) yang dikeluarkan International Bar Association (IBA) tahun 1987. Meskipun demikian, kode etik tersebut lebih memfokuskan pada kewajiban etika para arbiter daripada perilaku para advokat dalam persidangan arbitrase. Salah satu contoh tentang masalah etika dalam berarbitrase yang perlu diselesaikan, misalnya, adalah keharusan untuk menjaga kerahasiaan. Sebagaimana diketahui, salah satu alasan utama dipilihnya arbitrase oleh para pihak adalah sifat tertutupnya pemeriksaan sengketa dalam arbitrase dibandingkan jika diselesaikan melalui pengadilan. Hampir semua lembaga arbitrase mengharuskan proses persidangan arbitrase dan hasil-hasilnya dirahasiakan.

Kewajiban untuk memelihara kerahasiaan dalam arbitrase dapat menjadi masalah etika, jika misalnya terjadi perilaku menyimpang dari pengacara yang harus dilaporkan kepada organisasi profesinya. Pengungkapan hal ini dapat bertentangan dengan kewajiban-kewajiban menjaga kerahasiaan dalam berarbitrase.

Demikian pula, pengacara dan arbiter seharusnya tidak mengungkapkan proses arbitrase bagi tujuan-tujuan yang tidak relevan, misalnya mendapatkan keuntungan dari informasi "dalam", atau menggunakan informasi tersebut untuk keunggulan bersaing atau kepentingan bisnis lainnya, dan lain-lain. (Sebagai catatan: ringkasan suatu kasus arbitrase tanpa menyebutkannya secara mendetil untuk tujuan pendidikan atau pelatihan pada umumnya diizinkan).

Selain pelanggaran kerahasiaan tersebut, masih banyak persoalan etika yang perlu mendapat perhatian seperti bias dalam penjatuhan putusan, terjadinya penundaan, keadilan dan kejujuran dalam proses persidangan, dan lain-lain. Kesemuanya itu perlu diatur secara hatihati, tentunya dengan mempertimbangkan "keunikan" dari penyelesaian sengketa melalui arbitrase.

\section{Penyelesaian sengketa sebelum adanya Alternative Dispute Resolution (ADR)}

Pada dasarnya tidak seorangpun menghendaki terjadinya sengketa dengan orang lain. Tetapi dalam hubungan bisnis, masing-masing pihak harus mengantisipasi kemungkinan timbulnya sengketa yang dapat terjadi di kemudian hari. Sengketa yang perlu diantisipasi dapat timbul karena penafsiran mengenai bagaimana cara melaksanakan klausul-klausul perjanjian maupun disebabkan hal-hal lainnya. Dari berbagai macam penyelesaian sengketa bisnis, ada tiga penyelesaian yang umum digunakan, yaitu:

1. Adjudikatif

Mekanisme penyelesaian secara adjudikatif ditandai dengan kewenangan pengambilan keputusan oleh pihak ketiga dalam sengketa yang berlangsung diantara para pihak. 
Pihak ketiga dapat bersifat voluntary (sukarela) ataupun involuntary (tidak sukarela). Pada umumnya penyelesaian ini menghasilkan putusan yang bersifat win-lose solution.

\section{Konsensus/Kompromi}

Mekanisme penyelesaian sengketa secara konsensual ditandai dengan cara penyelesaian sengketa kooperatif/kompromi untuk mencapai solusi yang win-win solution.Kehadiran pihak ketiga kalaupun ada tidak mewakili kewenangan mengambil keputusan. Termasuk dalam hal ini misalnya negosiasi (perundingan), mediasi (penengahan), dan konsiliasi (permufakatan).

3. Quasi Adjudikatif

Mekanisme penyelesaian sengketa yang merupakan kombinasi antara unsure konsekuensi dan adjudikatif. Termasuk dalam mekanisme ini antara lain Med-Arb, Mini Trial, Ombudsman, dan lain-lain. Model penyelesaian ini juga sering disebut adjudikatif semu atau penyelesaian hibrida.

Disamping pembagian diatas, mekanisme penyelesaian sengketa bisnis dapat pula dibedakan menjadi dua, yaitu melalui jalur ligitasi dan jalur non ligitasi. Jalur ligitasi merupakan mekanisme penyelesaian perkara melalui jalur pengadilan dengan menggunakan pendekatan hukum (law approach) melalui aparat atau lembaga penegak hukum yang berwenang sesuai dengan peraturan perundang-undangan.

Pada dasarnya jalur ligitasi merupakan the last resort atau ultimatum remedium, yaitu sebagai upaya terakhir manakala penyelesaian sengketa secara kekeluargaan atau perdamaian di luar pengadilan ternyata tidak menemukan titik temu atau jalan keluar. Sedangkan jalur non ligitasi adalah mekanisme penyelesaian sengketa di luar pengadilan, tetapi menggunakan mekanisme yang hidup dalam masyarakat yang bentuk dan macamnya sangat bervariasi, seperti musyawarah, perdamaian, kekeluargaan, penyelesaian adat, dan lain-lain. Salah satu cara yang sekarang sedang berkembang dan diminati oleh para pelaku bisnis adalah melalui lembaga ADR (Alternative Dispute Resolution)

\section{Kesimpulan}

Berdasarkan Pembahasan ini sengketa bisnis adalah sengketa yang timbul diantara para pihak-pihak yang terlibat dalam berbagai macam kegiatan bisnis atau perdagangan, termasuk didalamnya unsur-unsur yang lebih luas, seperti pekerjaan, profesi, penghasilan, mata pencaharian, dan keuntungan.

ADR (Alternative Dispute Resolution) merupakan suatu mekanisme penyelesaian sengketa di luar pengadilan yang dianggap lebih efektif, efisien, cepat dan biaya murah serta menguntungkan kedua belah pihak (win-win solution) yang berperkara Urgensi penyelesaian sengketa bisnis di luar pengadilan ditandai oleh kecenderungan masyarakat kalangan bisnis mendayagunakan penyelesaian sengketa tersebut, yang dilandasi oleh beberapa factor yang menempatkannya dengan berbagai keunggulan, antara lain factor ekonomis, factor budaya hukum, factor luasnya ruang lingkup permasalahan yang dapat di bahas, factor pembinaan hubungan baik para pihak dan factor proses. 
Mediasi merupakan suatu proses informal yang ditujukan untuk memungkinkan para pihak yang bersengketa mendiskusikan perbedaan-perbedaan mereka secara "pribadi" dengan bantuan pihak ketiga yang netral.Seorang mediator dalam suatu mediasi seharusnya tetap bersikap netral, selalu membina hubungan baik, berbicara dengan bahasa para pihak, mendengarkan secara aktif, menekankan pada keuntungan potensial, meminimalkan perbedaan-perbedaan, dan menitik beratkan persamaan.Tujuannya adalah untuk membantu para pihak bernegosiasi secara lebih baik atas suatu penyelesaian.

Lembaga mediasi berfungsi untuk menyediakan sarana bagi pihak-pihak yang bersengketa untuk mencari penyeklesaian secara win-win solution berdasarkan kesepakatan. Oleh karena itu kiranya perlu diatur adanya sanksi sebagai penekan pendayagunaan mediasi. Barangkali perlu di contoh sistem peradilan atau praktek mediasi pengadilan dari Negara lain yang sudah mapan kelembagaannya, yang memberikan sanksi berupa putusan "batal" jika hakim tidak member kesempatan para pihak untuk menempuh mekanisme mediasi.

Melakukan koreksi secara terus menerus atas Undang-Undang Nomor 30 Tahun 1999 yang mengatur tentang Arbitrase dan Alternative Penyelesaian Sengketa karena dalam UndangUndang tersebut tidak memberikan pengertian yang jelas tentang berbagai bentuk penyelesaian sengketa termasuk tentang mediasi, kecuali Arbitrase. Bahkan proses atau mekanisme masingmasing bentuk lembaganya juga tidak diatur.

\section{Saran}

Adapun beberapa saran untuk meningkatkan kualitas arbitrase online :

a. Kepada DPR, perlu adanya penambahan peraturan yang mengatur tentang arbitrase online sehingga para pelaku usaha tidak ragu untuk melakukan aktifitas jual-beli elektronik demi kepastian hukum.

b. Badan Arbitrase Nasional Indonesia tidak ragu-ragu untuk menyelenggarakan penyelesaian sengketa secara online.

c. Pemerintah haruslah menyediakan infrastruktur telekomunikasi dan membentuk lembaga baru untuk menangani perkara arbitrase online karena semakin majunya teknologi tidak menutup kemungkinan banyaknya sengketa online yang timbul.

\section{DAFTAR PUSTAKA}

\section{Buku :}

Amirudin, Pengantar Metode Penelitian Hukum, Raja Grafindo Persada, Jakarta, 2004.

Bahder Johan Nasution, Metode Penelitian Ilmu Hukum, Mandar Maju, Bandung, 2008.

Cholid Narbuko, Abu Achmadi, 1997, Metodologi Penelitian, Bumi Pustaka, Jakarta.

Frans Hendra Winarta, Hukum Penyelesaian Sengketa Arbitrase Nasional Indonesia dan Internasional, 2011, Sinar Grafika, Jakarta, hlm.121

Huala Adolf, Hukum Perdagangan Internasional, PT.Rajagrafindo Persada, Jakarta,2006, hlm. 168 . 
Johnny Ibrahim, Teori dan Metodologi Penelitian Hukum Normatif, Bayumedia, Malang, 2007.

Khairandy, Ridwan, 2007. Hukum Perdata dalam Perkembangan. Yogyakarta. FH UII Press.

M. Arsyad Sanusi, H., 2000. Problema Hukum Transasksi E-Commerce. Varia Peradilan No.176 Juni 2000. Jakarta: Mahkamah Agung

Mochamad Basarah, Prosedur Alternatif Penyelesaian Sengketa Arbitrase Tradisional dan Modern (online), 2011, Genta Publishing, Yogyakarta.

\section{Jurnal :}

Abdul Halim Barkatullah, "Penerapan Arbitrase Online dalam Penyelesaian Sengketa Transasksi E-Commerce”, Jurnal Hukum tahun 2010.

\section{Internet :}

https://www.kajianpustaka.com/2018/10/pengertian-jenis-penyebab-dan-penyelesaiansengketa.html\#: :text=Sengketa\%20atau\%20dalam\%20bahasa\%20inggris, antara\%20satu\%2 Odengan\%20yang\%201ain. Pengertian sengketa dan pengelompokannya. Diakses oleh Muchlisin Riadi. (Oktober 24, 2018)

https://www.hukumonline.com/klinik/detail/ulasan/lt56d6a120b03b3/alternatif-penyelesaiansengketa-secara-

online/\#: :text=Alternatif\%20Penyelesaian\%20Sengketa\%20adalah\%20lembaga, $\% 2 \mathrm{C} \% 20 \mathrm{k}$ onsiliasi\%2C\%20atau\%20penilaian\%20ahli. Cara alternatif penyelesaian sengketa. Diakses oleh Alfin Sulaiman, S.H.,M.H. (Selasa, 22 August 2017)

https://www.jogloabang.com/pustaka/uu-30-1999-arbitrase-alternatif-penyelesaiansengketa\#: :text=Arbitrase \%20menurut\%20Undang\%2DUndang\%20Nomor,oleh\%20para\% 20pihak\%20yang\%20bersengketa. Pengaturan arbitrase, UU No. 30 Tahun 1999. Diakses pada Tanggal 01 Agustus 2020

https://bplawyers.co.id/2017/03/02/menyoal-kelebihan-dan-kekurangan-arbitrase-diindonesia/ Kelebihan dan kelemahan arbitrase. Diakses pada Tanggal 2 Maret 2017

http://www.bapmi.org/in/arbitrators_codeofconduct.php Etika dalam berabitrase. Diakses pada Tanggal 28 Maret 2021

https://www.hukumonline.com/klinik/detail/ulasan/lt52897351a003f/litigasi-dan-alternatifpenyelesaian-sengketa-di-luar-pengadilan/ Penyelesaian sengketa sebelum adanya Alternative Dispute Resolution (ADR). Diakses oleh Tri jata Ayu Pramesti, S.H. (Jum'at 10 Juli 2020). 